See discussions, stats, and author profiles for this publication at: https://www.researchgate.net/publication/291377454

\title{
Dual diagnoses among detained female systematic offenders
}

Article $\cdot$ February 2016

DOI: 10.1108/ADD-08-2015-0020

READS

27

6 authors, including:

Eric Blaauw

Hanzehogeschool Groningen

49 PUBLICATIONS 784 CITATIONS

SEE PROFILE 


\section{Emerald Insight}

\section{Advances in Dual Diagnosis}

Dual diagnoses among detained female systematic offenders

Eric Blaauw Gytha Strijker Yentl Boerema Eric Veersma Margreet van der Meer-Jansma Gabriel Anthonio

\section{Article information:}

To cite this document:

Eric Blaauw Gytha Strijker Yentl Boerema Eric Veersma Margreet van der Meer-Jansma Gabriel Anthonio , (2016),"Dual diagnoses among detained female systematic offenders", Advances in Dual Diagnosis, Vol. 9 Iss 1 pp. 7 - 13

Permanent link to this document:

http://dx.doi.org/10.1108/ADD-08-2015-0020

Downloaded on: 01 February 2016, At: 23:47 (PT)

References: this document contains references to 18 other documents.

To copy this document: permissions@emeraldinsight.com

The fulltext of this document has been downloaded 7 times since 2016*

\section{Users who downloaded this article also downloaded:}

Hattie Catherine Ann Moyes, Joshua James Heath, Lucy Victoria Dean, (2016),"What can be done to improve outcomes for prisoners with a dual diagnosis?", Advances in Dual Diagnosis, Vol. 9 Iss 1 pp. 14-25 http://dx.doi.org/10.1108/ ADD-07-2015-0016

Nat Wright, Pamela Walters, John Strang, (2016),"Dual diagnosis in prisons: management of co-existing substance use and mental health disorders", Advances in Dual Diagnosis, Vol. 9 Iss 1 pp. - http://dx.doi.org/10.1108/ADD-12-2015-0025

Vanessa Melton, Sue Ledwith, (2016),"Node-link mapping, an asset?", Advances in Dual Diagnosis, Vol. 9 Iss 1 pp. $26-37$ http://dx.doi.org/10.1108/ADD-07-2015-0019

Access to this document was granted through an Emerald subscription provided by Token:J ournalAuthor:633DE16BE24D-4E93-B9D5-C2ED79DFB919:

\section{For Authors}

If you would like to write for this, or any other Emerald publication, then please use our Emerald for Authors service information about how to choose which publication to write for and submission guidelines are available for all. Please visit www. emeraldinsight. com/ authors for more information.

\section{About Emerald www.emeraldinsight.com}

Emerald is a global publisher linking research and practice to the benefit of society. The company manages a portfolio of more than 290 journals and over 2,350 books and book series volumes, as well as providing an extensive range of online products and additional customer resources and services.

Emerald is both COUNTER 4 and TRANSFER compliant. The organization is a partner of the Committee on Publication Ethics (COPE) and also works with Portico and the LOCKSS initiative for digital archive preservation.

*Related content and download information correct at time of download. 


\section{Dual diagnoses among detained female systematic offenders}

\section{Eric Blaauw, Gytha Strijker, Yentl Boerema, Eric Veersma, Margreet van der Meer-Jansma and Gabriel Anthonio}

\author{
Dr Eric Blaauw is Forensic \\ Psychologist at \\ Verslavingszorg Noord \\ Nederland, Groningen, \\ The Netherlands. \\ Gytha Strijker is based at \\ Verslavingszorg Noord \\ Nederland, Groningen, \\ The Netherlands. \\ Yentl Boerema is GZ \\ Psycholoog I.O. at \\ Verslavingszorg Noord \\ Nederland, Groningen, \\ The Netherlands. \\ Eric Veersma is based at Dienst \\ Justitiële Inrichtingen, Zwolle, \\ The Netherlands. \\ Margreet van der Meer-Jansma \\ is based at Verslavingszorg \\ Noord Nederland, Groningen, \\ The Netherlands. \\ Dr Gabriel Anthonio is \\ Director at Verslavingszorg \\ Noord Nederland, Groningen, \\ The Netherlands.
}

Received 20 August 2015 Revised 26 October 2015 27 November 2015

Accepted 1 December 2015

\begin{abstract}
Purpose - The purpose of this paper is to examine the prevalence of psychopathology including substance use disorders in a sample of detained female systematic offenders.

Design/methodology/approach - All case files of female systematic offenders who had been subjected to a special court order for systematic offenders in the period 2004-2014 were studied. A total of 81 fairly complete case files were selected for the study. These were all systematic offenders as they had been sentenced for at least 25 offences with an average of 102 offences over a period of 17.5 years.

Findings - All except one woman were addicted to substances in the past year, with an average duration of addiction of 21 years. In addition, 53 per cent were diagnosed with another DSM Axis I disorder and 73 per cent were diagnosed with a personality disorder. Furthermore, 32-59 per cent were found to have intellectual dysfunctions. In total, 12 per cent had one type of the above disorders, 43 per cent two types, 31 per cent three types and 14 per cent all four types. The prevalence rates of these disorders were higher than those reported in other prison studies.

Research limitations/implications - It is concluded that female systematic offenders can be characterised as problematic in many respects. Even in such a problematic group treatment can be provided.

Originality/value - The present study is the only study that provides prevalence data of mental disorders among female systematic offenders.
\end{abstract}

Keywords Treatment, Prison, Offenders, Female, Dual diagnosis, Substance use disorders, Mental disorder, Systematic offenders, Psychopathology

Paper type Research paper

\section{Introduction}

Substance use disorders and other mental disorders are highly prevalent in the general population, but are generally found to be even more common in prison populations (e.g. see Blaauw et al., 2000; Fazel and Danesh, 2002; Steadman et al., 2009). As such, there appears to be a link between psychopathology and criminal behaviours. This raises the question about how often psychopathology is present in a sample of prisoners with extensive criminal records and which psychopathology is most often present in such samples. In this manuscript, this question is addressed, by describing the results of a Dutch study about psychopathology and psychosocial problems in a sample of detained female systematic offenders. In addition, some attention is given to the question of how the apparent relationship between severe psychopathology and extensive criminal behaviours may be altered. Before addressing these questions and the results of the study, the epidemiology of psychopathology and on a special court order in The Netherlands that targets systematic offenders are discussed. 


\section{Epidemiology}

Large-scale epidemiological studies have shown that almost one in every five people (18 per cent) in the Dutch general population have suffered from a mental (DSM Axis I) disorder in the past year, of which 6 per cent had a substance use disorder (de Graaf et al., 2010). In the USA the year prevalence rate of any mental disorder was found to be 26.2 per cent, with substance use disorders in 3.8 per cent (Kessler et al., 2005). In England 23.0 per cent were found to have at least one psychiatric disorder in the past week and, on an annual basis, 24.2 per cent were hazardous drinkers and 3.4 per cent showed signs of dependence on drugs (McManus et al., 2009).

Studies have consistently revealed substantially higher prevalence of mental disorders in prisons. Current prevalence rates of mental disorders including substance use disorders and personality disorders were consistently found to be around 63 per cent in remand prisons in several countries (Blaauw et al., 2000). Larger variations, but consistently higher current prevalence rates than in community samples were found in studies in prisons for sentenced prisoners. Hereby, the prevalence rates of severe mental disorders appear to have remained stable over the last four decades (Fazel and Seewald, 2012). A systematic review of 13 studies that had used standardised diagnostic criteria for substance use disorders in prisoners on reception into prison revealed current prevalence rates of 18-30 per cent for alcohol abuse and dependence and 10-48 per cent for illicit drug use and dependence in male prisoners (Fazel et al., 2006).

Because serious mental disorders tend to be more common among female prisoners than among male prisoners (Fazel and Danesh, 2002; Steadman et al., 2009), the overall prevalence rates of mental disorders may also be higher among female prisoners. An Australian study found that 84 per cent of the female prisoners met the criteria for a mental disorder including substance harmful use and dependence in the previous year, with 57 per cent having a drug use disorder and 43 per cent having a personality disorder (Tye and Mullen, 2006). The aforementioned systematic review of 13 studies on substance use disorders in prisoners found current prevalence rates for female prisoners of 10-24 per cent for alcohol abuse and dependence and 30-60 per cent for illicit drug abuse and dependence (Fazel et al., 2006).

\section{Special court order (ISD)}

In the beginning of this century England and Wales started with the Drug Interventions Programme and the Prolific and other Priority Offenders Programme, which were designed to give offenders a choice between the cessation of offending with the acceptance of support in the form of rehabilitative programmes or to carry on offending resulting in prompt arrest and punishment (Wheelhouse, 2008). In the same period in The Netherlands intensive media attention was given to criminals with more than ten antecedents in their police record. Politicians pleaded that this group of systematic offenders should be targeted because they were supposed to be responsible for more than half of all crimes and nuisance acts in any given year. In reality, these systematic offenders indeed covered 60 per cent of all criminal career antecedents in the national database of known criminal suspects (Boerman et al., 2002), but had been responsible for about 20 per cent of all crimes in 1999 (Grapendaal and Van Tilburg, 2002). A high percentage nonetheless.

In 2002, the treatment of systematic offenders received special attention from the Dutch government in a governmental Security Note and in January 2003 the Minister of Justice launched the idea for placing specific persistent offenders in so-called Institutions for Systematic Offenders (in Dutch: ISD). At this time there was already some experience with a special court order for placing persistently offending drug users in secure settings for a period of two years and providing them with a treatment programme aimed at abstinence of substances. Judges could decide to impose this measure on reoffending drug users when they considered the personal circumstances of the drug users to be of more importance than the crimes committed. In addition, research had shown that the group of systematic offenders was a small group of people with evident psychiatric and psychosocial problems. Analysis of the national database of criminal suspects had shown that about 12 per cent of all suspects had more than ten antecedents in the police records (Versteegh et al., 2003) and that this group of systematic 
offenders could be characterised as hard drug dependent, alcohol dependent, mentally disordered, financially troubled, homeless and suffering of other psychosocial problems (Jacobs and Essers, 2003). The court order of ISD was instated in the Dutch criminal justice system in 2004.

The measure of ISD in its current form is a court order in which systematic offenders can be placed in a prison for a maximum of two years as a last resort measure (Openbaar Ministerie (Crown Council), 2013). Systematic offenders must have committed a crime that allows protective custody and must have been sentenced three or more times for offences in the past five years (article 38m Criminal Code). The presence or absence of psychopathology is not an inclusion or exclusion criterion for the measure. The measure was originally designed to incapacitate systematic offenders from reoffending by incarcerating them, but the measure also aims at reducing recidivism by trying to let systematic offenders adopt alternative behavioural patterns and lifestyle patterns (Openbaar Ministerie (Crown Council), 2013; see also Tollenaar and van der Laan, 2012). Annually, 200-300 systematic offenders are subjected to the measure of ISD and placed in one of the regional ISD prisons. All female ISD prisoners are placed in a prison in Zwolle, which is located in the east of The Netherlands.

It has been estimated on the basis of the number of crimes committed by the group of systematic offenders that a total of 5.7 court cases and 9.2 criminal offences per year per systematic offender have been prevented due to the incapacitation associated with the imprisonment (Tollenaar and van der Laan, 2012). The intention of reducing recidivism can still be improved greatly as it has been found that 72 per cent of the male systematic offenders reoffend within two years after the ISD measure. This percentage is, however, 12-16 per cent less than the percentage of systematic offenders who had been subjected to standard prison sentences (Tollenaar and van der Laan, 2012) and with a lower frequency than before the measure of ISD. Effects of the ISD measure for female systematic offenders are still unknown.

A study on case files of 97 systematic offenders that had been subjected to the measure of ISD showed that all systematic offenders have substance use disorders, with combinations of alcohol, cocaine or heroin being present in 70 per cent of the cases (Goderie, 2009). Although information about psychiatric disorders (21 per cent) or the diagnoses ( 20 per cent) was often missing in the case files, no less than 51 per cent were identified as suffering from a mental disorder.

\section{Method \\ Procedure}

With the approval of the Dutch Ministry of Security and Justice, all the personal files were gathered of all 102 women who had been subjected to the court order of ISD in the period 2004-2014 and placed in the ISD prison in Zwolle. All personal files consisted of the historical criminal records and at least one report of the probation service, that draws up a report for the court containing information about the use of alcohol and drugs, prior treatment, education and work, contacts with intimates and other people, prior crimes and criminal proceedings and indications of mental disorders and interaction problems. Most personal files consisted of several reports of the probation service and some files also contained psychiatric reports. Furthermore, the majority of the personal files also contained the report of a psychological examination as it had become standard procedure since 2008 to conduct such an examination when information was insufficient to draw up a treatment plan. Most of these examinations had been conducted by the primary author of the current manuscript, who had used questionnaires, neuropsychological tests, the Wechsler Adult Intelligence Scale, and interviews on the basis of the Structured Clinical Interview for DSM Disorders (SCID). All examinations addressed mental disorders according to DSM-IV-TR diagnostic criteria in the past year. A total of 21 personal files were omitted from the study because they contained scarce information about mental disorders and psychosocial functioning in the past year. The omitted personal files were predominantly from women who had been subjected to the court order of ISD between 2004 and 2008, and were not different from those in the final sample with respect to the age of the women and the number of prior offences. The final sample consisted of 81 personal files, representing all female systematic offenders that had been subjected to the court order of ISD. 


\section{Sample}

During the examination, the 81 women in the sample were between 24 and 64 years old, with an average of 41.3 years $(S D=7.5$ years). A total of 57 per cent had received only primary education and 4 per cent had received education at an advanced level. The majority (77 per cent) were born in The Netherlands.

The women had been sentenced for 25-421 offences in the past, with an average of 102 offences $(\mathrm{SD}=73$ offences). The majority of the current offences (88 per cent) were property offences. The first offence had been committed at an average age of 23.8 years ( $S D=7.8$ years), with a starting age between ten and 46 years. Thus, on average the women had been engaged in criminal behaviours for 17.5 years with on average 5.8 sentenced offences each year.

\section{Results}

\section{Substance abuse and dependence}

All except one woman had a substance use disorder in the past year. The vast majority (86 per cent) had been addicted to more than one substance, with cocaine (41 per cent), heroin (31 per cent) and alcohol (16 per cent) being the most common primary substance and with the combination of cocaine and heroin being the most frequently used common combination of substances (58 per cent). Many women were addicted to smoking cocaine and heroin, with fewer women inhaling or injecting these substances. All women had used their primary substance for more than five years, with 90 per cent for more than ten years and 49 per cent for more than 20 years. On average, they had been addicted for 21.0 years $(S D=7.5$ years).

\section{Other mental disorders}

A bit more than half of the women (53 per cent) met the diagnostic criteria of one (42 per cent) or more (11 per cent) DSM-IV Axis I disorders beside a substance use disorder, with mood disorders (22 per cent) being the most frequently diagnosed comorbid disorder but with also a high frequency of psychotic disorders (17 per cent). In addition, about three quarters of the women (73 per cent) met the diagnostic criteria of a personality disorder, with the highest occurrences of borderline (29 per cent), antisocial personality disorder (21 per cent) and personality disorder not otherwise specified (30 per cent). Furthermore, 59 per cent of the women with known IQ scores and 32 per cent of all women were found to have borderline intellectual functioning or an intellectual disability.

\section{Any disorder}

All women were diagnosed with at least one category of mental disorders, including substance use disorders, psychiatric disorders, personality disorders and impaired intellectual functioning. Hereby, 12 per cent were diagnosed with one of these types of disorders, 43 per cent with two types, 31 per cent with three types and 14 per cent with all four types of mental disorders.

\section{Psychosocial functioning}

The majority of the women had one (36 per cent) or more (35 per cent) children, but none of the women were the primary caretaker of their children. About half of the children were raised by family and about half were raised in an institution or a foster home.

The vast majority of the women (88 per cent) had a history of mental health care. In addition, 43 per cent admitted to having a history of prostitution and 61 per cent to having a history of homelessness. None of the women had a job and 86 per cent did not have housing of their own.

\section{Discussion}

The majority of the female systematic offenders in the present study were found to have long histories of extensive criminal behaviours and highly problematic substance use disorders, given that many had smoked large amounts of both cocaine and heroin for many years. Almost all 
women were also diagnosed with a mental disorder, a personality disorder or borderline intellectual functioning or combinations of these mental states. Furthermore, many were found to have problematic psychosocial functioning and the vast majority had a history of mental health care. Hereby, the prevalence rate of 100 per cent of any mental disorder is high in comparison to that in other prison samples (cf. Blaauw et al. , 2000) or in samples of detained women (cf. Tye and Mullen, 2006). In addition, the prevalence rates of substance use disorders (99 per cent), personality disorders (73 per cent) and psychotic disorders (17 per cent) in the present study were found to be higher than those in other studies (cf. Fazel and Danesh, 2002). Thus, it seems reasonable to conclude that female systematic offenders can be characterised as highly problematic in many respects and that psychopathology appears to be more often present and more severe among systematic offenders than in other prison samples. Conversely, it seems reasonable to conclude that female systematic offenders can be characterised as a group of resilient women.

As with other studies in samples of people with comorbid mental disorders, the present study struggled with the problem of diagnosing mental disorders in the presence of substance use disorders and problematic situations such as homelessness and financial problems. All women had been detained for at least a month and consequently had been in a highly structured environment with stable housing and nourishing and abstinence of alcohol and drugs, which made it easier to identify comorbid disorders because the women were struggling less from withdrawal symptoms or from intoxications. Nonetheless, it is still possible that symptoms of disorders were masked by (withdrawal) symptoms of the substance use disorders or were caused by remaining effects of these disorders. In addition, prevalence rates may be slightly different from the rates that were presented because the present study did not make use of a standardised clinical interview and relied on the diagnoses made by only one mental health professional. However, the examinations were quite extensive and conducted on the basis of the SCID. As such, the flaws of the study are not likely to seriously threaten the conclusion that female systematic offenders can be characterised as highly problematic in many respects.

The high morbidity of substance use disorders, mental disorders, personality disorders and impaired intellectual functioning stresses the importance of thorough diagnostic examinations of female systematic offenders in all these areas of functioning. After all, no less than 31 per cent of the female prisoners were found to have three areas of major concern or to be suffering from quadruple quandary (14 per cent) with almost all women having a history of mental health treatment (88 per cent). It may be clear that without a thorough examination many of these disorders would have remained unnoticed. It is less clear, however, whether this omission would also have led to needless suffering of the women during their detention. After all, many disorders do not necessarily require treatment due to their limited severity or tendency to decrease over time. Moreover, the structure provided during detention may even be beneficial for the course of certain disorders such as psychotic disorders (e.g. see Walker et al., 2014).

An important question is whether it is possible to provide effective treatment when people suffer from so many concurrent disorders that have existed over longer periods of time. Another question is whether it is possible to keep highly problematic systematic offenders from reoffending. This latter question is even more significant with the knowledge that the woman in the present sample had been engaged in criminal behaviours for an average of 17.5 years and had generally committed over 100 offences. In other words, how can the link between psychopathology and criminal behaviours be altered when both extensive pathology and extensive criminal behaviours are present? Unfortunately, this question cannot be answered by the present study because the study did not address criminal recidivism after the court order of ISD, nor did it address effects of different kind of treatments. However, in some cases it was fairly easy to choose the desired treatment because the relationship between the psychopathology and criminal behaviours was unequivocal. For example, one woman had lived her live according to societal norms and without psychopathology, until at the age of 29 her ten-year-old son suddenly died. Overwhelmed by grief she started consuming alcohol in order to ease the pain. She lost her job and left her spouse in the year thereafter and started stealing in order to stay alive. During detention she functioned at a cognitive level that indicated the presence of an intellectual 
disability, despite the fact that she had a high school degree and had functioned at a good level. During detention it was possible to provide her with Eye Movement Desensitization and Reprocessing treatment to deal with the trauma of her loss. With an improvement of her intellectual functioning and less symptoms of Post-Traumatic Stress Syndrome there was no longer a need to soothe her pain with alcohol and she was able to get her life together again without having the need to steal in order to stay alive. The example shows that even in extremely problematic cases or when all resources seem to have been exhausted, it may still be possible to provide effective treatment of psychopathology and to reduce criminal recidivism.

\section{References}

Blaauw, E., Roesch, R. and Kerkhof, A.J.F.M. (2000), "Mental health care in European prison systems", International Journal of Law and Psychiatry, Vol. 23 Nos 5-6, pp. 649-63.

Boerman, F., van Tilburg, W. and Grapendaal, M. (2002), Landelijke criminaliteitskaart 1999. Aangifte- en verdachtenanalyse op basis van HKS-gegevens (National Crime Map 1999. Accusations and Suspects Analyses on the Basis of HKS Data), KLPD, Zoetermeer.

de Graaf, R., Have ten, M. and van Dorsselaer, S. (2010), De psychische gezondheid van de Nederlandse bevolking (The Mental Health of the Dutch Population), Trimbos Instituut, Utrecht.

Fazel, S. and Danesh, J. (2002), "Serious mental disorder in 23000 prisoners: a systematic review of 62 surveys", Lancet, Vol. 359 No. 9306, pp. 545-50.

Fazel, S. and Seewald, K. (2012), "Severe mental illness in 33.588 prisoners worldwide: systematic review and meta-regression analysis”, British Journal of Psychiatry, Vol. 200 No. 5, pp. 364-73.

Fazel, S., Bains, P. and Doll, H. (2006), "Substance abuse and dependence in prisoners: a systematic review", Addiction, Vol. 101 No. 2, pp. 181-91.

Goderie, M. (2009), Problematiek en hulpvragen van stelselmatige daders (Problems and Needs of Systematic Offenders), Verwey-Jonker Instituut, Utrecht.

Grapendaal, M. and van Tilburg, W. (2002), "Veelplegers in Nederland (Repeated offenders in The Netherlands)", Tijdschrift voor Criminologie, Vol. 44 No. 3, pp. 214-30.

Jacobs, M. and Essers, A. (2003), "De misdaad van de straat. Op zoek naar achtergronden van veelpleger" ("The crimes of the streets. Searching for the backgrounds of the veelpleger"), Tijdschrift voor Criminologie, Vol. 45 No. 2, pp. 140-52.

Kessler, R.C., Chiu, W.T., Demler, O. and Walters, E.E. (2005), "Prevalence, severity, and comorbidity of 12-month DSM-IV disorders in the national comorbidity survey replication", Archives of General Psychiatry, Vol. 5 No. 62, pp. 617-27.

McManus, S., Meltzer, H., Brugha, T., Bebbington, P. and Jenkins, R. (Eds) (2009), Adult Psychiatric Morbidity in England, 2007. Results of a Household Survey, National Centre for Social Research and the Department of Health Sciences, University of Leicester, London.

Openbaar Ministerie (Crown Council) (2013), "Maatregel Inrichting Stelselmatige Daders (ISD)" (“Court order Institutions Systematic Offenders"), available at: http://om.nl/onderwerpen/veelplegersmaatregel_inrichting (accessed 3 September 2013).

Steadman, H.J., Osher, F.C., Robbins, P.C., Case, B. and Samuels, S. (2009), "Prevalence of serious mental illness among jail inmates", Psychiatric Services, Vol. 60 No. 6, pp. 761-5.

Tollenaar, N. and van der Laan, A.M. (2012), "Effecten van de ISD-maatregel: technische rapportage” (“Effects of SD measure: technical report"), WODC, The Hague.

Tye, C.S. and Mullen, P.E. (2006), "Mental disorders in female prisoners", Australian and Zew Zealand Journal of Psychiatry, Vol. 40 No. 3, pp. 266-71.

Versteegh, P., Janssen, J. and Bernasco, W. (2003), "Beginners, doorstromers en veelplegers. Carrièrecriminaliteit in de politieregio Haaglanden" ("Beginner, sustainers and veelplegers. Carreer criminality in the police region Haaglanden"), Tijdschrift voor Criminologie, Vol. 45 No. 2, pp. 127-39. 
Walker, J., Illingworth, C., Canning, A., Garner, E., Woolley, J., Taylor, P. and Amos, T. (2014), "Changes in mental state associated with prison environments: a systematic review", Acta Psychiatrica Scandinavica, Vol. 129 No. 6, pp. 427-36.

Wheelhouse, P. (2008), "Interventions with drug misusing offenders and prolific and other priority offenders", paper prepared for the 135th International Senior Seminar of the United Nations Asia and Far East Institute for the Prevention of Crime and the Treatment of Offenders (UNAFEI), Tokyo, January.

\section{Corresponding author}

Dr Eric Blaauw can be contacted at: e.blaauw@vnn.nl

For instructions on how to order reprints of this article, please visit our website: www.emeraldgrouppublishing.com/licensing/reprints.htm

Or contact us for further details: permissions@emeraldinsight.com 